\title{
The Hearing Threshold of Employees Exposed to Noise Generated by the Low-Frequency Ultrasonic Welding Devices
}

\author{
Adam DUDAREWICZ, Kamil ZABOROWSKI, Paulina RUTKOWSKA-KACZMAREK \\ Małgorzata ZAMOJSKA-DANISZEWSKA, Mariola ŚLIWIŃSKA-KOWALSKA \\ Ewa ZAMYSŁOWSKA-SZMYTKE, Małgorzata PAWLACZYK-ŁUSZCZYŃSKA
}

\author{
Nofer Institute of Occupational Medicine in Eódź \\ Św. Teresy od Dzieciątka Jezus 8, 91-348 Łódź, Poland; e-mail: adudar@imp.lodz.pl
}

(received March 15, 2016; accepted December 7, 2016)

\begin{abstract}
The aim of the study was to assess the hearing threshold levels (HTLs) in employees exposed to noise generated by low-frequency ultrasonic technological equipment in comparison with the HTLs of workers exposed to audible noise at the similar $A$-weighted equivalent-continuous sound pressure level.

The study includes measurements of ultrasonic and audible noise at workplaces and hearing tests, i.e. conventional pure-tone audiometry and extended high-frequency audiometry. The study group comprised 90 workers, aged $41.4 \pm 10.0$ years (mean $\pm \mathrm{SD}$ ), exposed for $17.3 \pm 9.8$ years to noise generated by ultrasonic devices at mean daily noise exposure level $\left(\left\langle L_{\mathrm{EX}, 8 \mathrm{~h}}\right\rangle\right)$ of $80.6 \pm 2.9 \mathrm{~dB}$. The reference group consists of 156 subjects, exposed to industrial noise (without ultrasonic components) at similar $A$-weighted equivalent-continuous sound pressure level $\left(\left\langle L_{\mathrm{EX}, 8 \mathrm{~h}}\right\rangle=81.8 \pm 2.7 \mathrm{~dB}\right)$, adjusted according to age $(39.8 \pm 7.7$ years), gender and job seniority (14.0 \pm 7.0 years). This group was selected from database collected in the Nofer Institute of Occupational Medicine. Audiometric hearing threshold levels in the frequency range of $0.5-6 \mathrm{kHz}$ were similar in both groups, but in the frequency range of $8-12.5 \mathrm{kHz}$ they were higher in the group of employees exposed to ultrasonic noise.

The findings suggest that differences in the hearing threshold (at high frequencies) in analyzed groups may be due to differences in spectral composition of noise and show the need to continue the undertaken studies.
\end{abstract}

Keywords: noise-induced hearing loss; noise; ultrasonic noise; occupational exposure.

\section{Introduction}

Ultrasound is acoustic vibrations with frequencies above $16 \mathrm{kHz}$. Depending on the frequency, there are different methods for their generation, their uses and mechanisms of influence on living organisms vary, which implies division into low-frequency ultrasound (below $100 \mathrm{kHz}$ ) and high-frequency ultrasound (above $100 \mathrm{kHz}$ ). Low-frequency ultrasound (below $40 \mathrm{kHz}$ ) propagating in air and high-frequency audible sounds (above $10 \mathrm{kHz}$ ) are referred to as ultrasonic noise (PAWLACZYK-ŁUSZCZYŃSKA et al., 2001a).

There is a constant interest in the application of technologies based on low-frequency ultrasound in medicine and industry. Furthermore, there are many machines unintentionally generating noise in the frequency range $10-40 \mathrm{kHz}$.

The study of ultrasonic noise impact (low-frequency airborne ultrasound) on the human body began in the 40s and 50s together with the introduction of industrial devices using ultrasonic energy of low frequencies. In those times research reported complaints such as headaches and dizziness, excessive fatigue and weakness, nausea, vomiting, feeling of fullness in the ears and impaired neuromuscular coordination reported by the personnel operating such devices. During that period, a group of the aforementioned clinical symptoms of autonomic dysfunction was described as "ultrasonic disease". However, the term is no longer in use.

Generally, interest in the impact of low-frequency ultrasonic noise lasted almost to the mid-80s. Later much less attention was paid to this issue (AстоN, Hill, 1977; Grzesik, Pluta, 1983; 1986; PawlaCZYK-ŁUSZCZYŃSKA et al., 2001a). A review of current state of knowledge on the influence of ultrasonic noise on humans has been recently presented by SMAGOWSKA and PAWLACZYK- ŁUSZCZYŃSKa (2013). 
The first proposals of occupational exposure limits for ultrasonic noise were prepared by individual researchers at the turn of the $60 \mathrm{~s}$ and $70 \mathrm{~s}$ (ACTON, HILL, 1977). They were based on two fundamental assumptions. First of all - high-frequency audible components $(10-20 \mathrm{kHz})$ can cause nuisance, tinnitus, headaches, fatigue and nausea. Secondly - the high-level ultrasonic component (above $20 \mathrm{kHz}$ ) may cause hearing damage. Thus, the limit values were set at such a level which would prevent any subjective or auditory effects in any exposed individuals (ACTON, Hill, 1977), (PAWLACZYK-ŁUSZCZYŃSKA et al., 2001a).

So far the European Union has not established special regulations on ultrasonic noise (low-frequency airborne ultrasound), though for more than twenty years protection against the negative effects of occupational exposure to noise has been one of the priority actions in the field of safety, hygiene and health in the workplace. Such rules are applied in some European countries e.g. Sweden as well as in the US, Canada, Russia and Japan (LAwTon, 2001) (see Fig. 1). Recommendations for methods of measuring ultrasonic noise include international standard ISO 9612:1997.

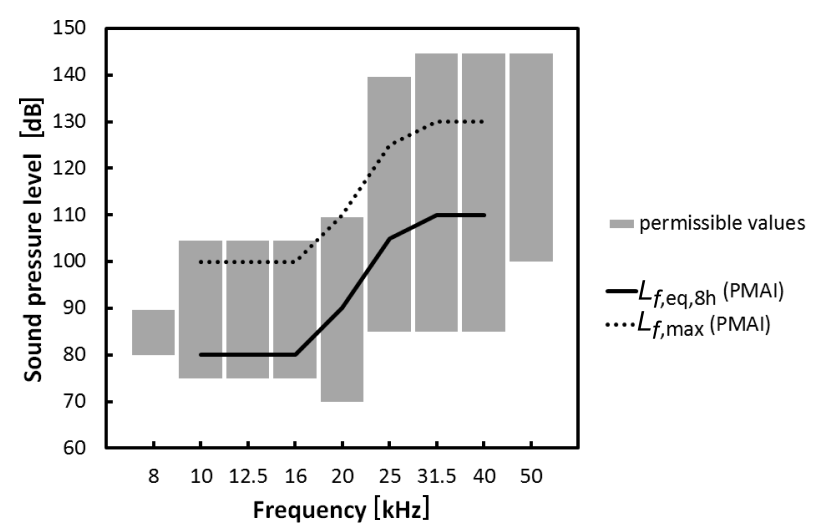

Fig. 1. The ranges of values of the maximum permissible levels applied in different countries (gray bars show ranges of sound pressure level) and the Polish maximum admissible intensity (PMAI) values. $L_{f, \max }$ is a maximum sound pressure level in the $1 / 3$-octave frequency bands (dotted line) and $L_{f, \text { eq, } 8 \mathrm{~h}}$ is an equivalent-continuous sound pressure level normalized to nominal 8-hour working day in one-third-octave frequency bands (solid line).

In Poland, the first proposals of hygienic standards on ultrasonic noise were prepared in the late $70 \mathrm{~s}$, but ultrasonic noise was introduced to the list of the harmful hazards in the work environment with maximum admissible intensity (MAI) values in 1989, while Polish Standard (PN-86/N-01321) was developed in 1986. In 2001, the MAI values on ultrasonic noise were amended and those changes are still valid (Ordinance by the Minister of Labor and Social Policy, 2014) (see Fig. 1).

The aim of this study was to assess the hearing status of employees exposed to noise generated by lowfrequency ultrasonic technological equipment in comparison with the hearing status of workers exposed to audible noise at the similar $A$-weighted sound pressure level and hearing status in appropriate non-exposed to noise population.

\section{Study design}

\subsection{Noise exposure}

In order to identify workplaces with exposure to audible and ultrasonic noise, the measurements of a) the equivalent-continuous $A$-weighted sound pressure level (SPL), b) maximum $A$-weighted SPL, c) peak $C$ weighted SPL, d) equivalent-continuous and maximum SPLs in 1/3-octave bands in the frequency range from 0.020 to $40 \mathrm{kHz}$, were carried out. These measurements were performed taking into account the measurement procedure for ultrasonic noise (PAWLACZYKŁUSZCZYŃSKA et al., 2001b) and recommendation of the Polish Standards (PN-N-01307:1994 and PN-EN ISO 9612:2011) on the assessment of occupational exposure to (audible) noise. Generally, the noise measurements were performed in 12 various factories.

\subsection{Hearing status}

Usually, due to the specificity of technological processes and work organization, it is not possible to find workers who were exposed exclusively to ultrasonic noise. Thus, the study group comprised 90 workers exposed both to ultrasonic noise and audible noise.

The majority of examined work posts (48 from 70) were located in four factories where ultrasonic welders and welding automats were used. Thus, hearing tests and questionnaire surveys were carried out among workers of these factories.

Their hearing status was examined using pure-tone audiometry $(0.5-8 \mathrm{kHz})$ and extended high-frequency (EHF) audiometry in the frequency range of up to $16 \mathrm{kHz}$. Hearing thresholds for the conventional frequencies $(0.5$ to $8 \mathrm{kHz})$ were obtained using clinical audiometer (Audio 4002, Videomed Smart Solution, Poland) and supra-aural headphones with sound-excluding earcups (Holmco P-81, Holmberg GMBH\&CO. KG Electroacoustik, Germany). Puretone hearing thresholds at EHFs were determined using the same audiometer with the Sennheiser HDA 200 earphones (Sennheiser Co, Germany) with soundexcluding earcups. Hearing tests were carried out in quiet rooms where the background noise did not exceed $30 \mathrm{~dB}(\mathrm{~A})$.

Additionally, all workers were interviewed using a questionnaire developed by the authors of this article to collect information on their age, education, and work history as well as past and present exposure to ultrasonic and audible noise.

The individual exposure to ultrasonic noise and the audible noise in the course of occupational activity was determined based on the questionnaire data and noise measurement results. 
The individual exposure to ultrasonic noise was characterized by the equivalent-continuous sound pressure levels normalized to nominal 8-hour working day in $1 / 3$-octave frequency bands $\left(L_{f, \text { eq, } 8 \mathrm{~h}}\right.$ in $\mathrm{dB}$ ) expressed as an energy mean of ultrasonic noise exposures at different work posts where subjects worked in current workplaces. The audible noise was characterized by noise exposure level normalized to nominal 8-hour working day averaged over the whole period of exposure to noise $\left(\left\langle L_{\mathrm{EX}, 8 \mathrm{~h}}\right\rangle\right)$. To obtain more accurate assessment of exposure to audible noise, the work stands without exposure to ultrasonic noise were also taken into account.

Additional measure useful for selection of reference group was a total noise immission level $L_{I M}$ (calculated using the following formula: $L_{\mathrm{IM}}=\left\langle L_{\mathrm{EX}, 8 \mathrm{~h}}\right\rangle+$ $10 \cdot \log \left(T / T_{0}\right)$, where $T$ is the length of exposure in years and $T_{0}$ is a period of one year).

The reference group consisted of 156 subjects exposed to industrial noise (without ultrasonic components) adjusted according to age, gender, internship and averaged daily noise exposure level $\left(\left\langle L_{\mathrm{EX}, 8 \mathrm{~h}}\right\rangle\right)$. This group was selected from database collected in the Nofer Institute of Occupational Medicine. The aforesaid database contained the results of previous research on the hearing status in people occupationally exposed to noise, including audiometric hearing threshold levels up to $16 \mathrm{kHz}$. Data on subjects' age, gender and exposure to noise were used to select an appropriate reference group. Characteristics of the study and the reference group are summarized in Table 1.

Table 1. Characteristics of the study and the reference groups $\left(\left\langle L_{\mathrm{EX}, 8 \mathrm{~h}}\right\rangle\right.$ is the noise exposure level normalized to nominal 8-hour working day averaged by whole period of exposure to noise and $L_{\mathrm{IM}}$ is the total noise imission level).

\begin{tabular}{|c|c|c|}
\hline & $\begin{array}{c}\text { Study group } \\
\text { exposed } \\
\text { to ultrasonic } \\
\text { and audible noise }\end{array}$ & $\begin{array}{c}\text { Reference } \\
\text { group exposed } \\
\text { to audible } \\
\text { noise }\end{array}$ \\
\cline { 2 - 3 } & \multicolumn{2}{|c|}{ Mean \pm standard deviation } \\
\hline Age [years] & $41.9 \pm 10.0$ & $39.8 \pm 7.7$ \\
\hline Length of work [years] & $17.3 \pm 9.8$ & $14.0 \pm 7.3$ \\
\hline$L_{\mathrm{EX}, 8 \mathrm{~h}[\mathrm{~dB}]}[\mathrm{dB}]$ & $90.6 \pm 2.9$ & $81.8 \pm 2.7$ \\
\hline$L_{\mathrm{IM}}[\mathrm{dB}]$ & $92.1 \pm 15.3$ & $92.5 \pm 10.4$ \\
\hline
\end{tabular}

Furthermore, distributions of hearing threshold levels in appropriate non-noise exposed population were calculated up to $8 \mathrm{kHz}$ according to PN-EN ISO 7029:2004, while median values above $8 \mathrm{kHz}$ - according to (JILEK et al., 2014).

\section{Results}

\subsection{Noise exposure}

The noise measurements in our study involved 70 work posts in 12 factories. About 500 samples of ul- trasonic noise and 280 samples of audible noise were collected. The results of SPL measurements at all examined work posts are presented in Tables $2-3$ and Fig 2. Generally, the exceeding of the PMAI values for the ultrasonic noise was found in approx. $35 \%$ of cases, and for the audible noise in about $23 \%$ of cases.

Figure 3 presents sound pressure levels in $1 / 3-$ octave bands (in the frequency range from 10 to $40 \mathrm{kHz}$ ) generated by welders from selected four factories, while Table 4 shows noise exposure levels $L_{\mathrm{EX}, 8 \mathrm{~h}}$ in workers' under study (from these factories).

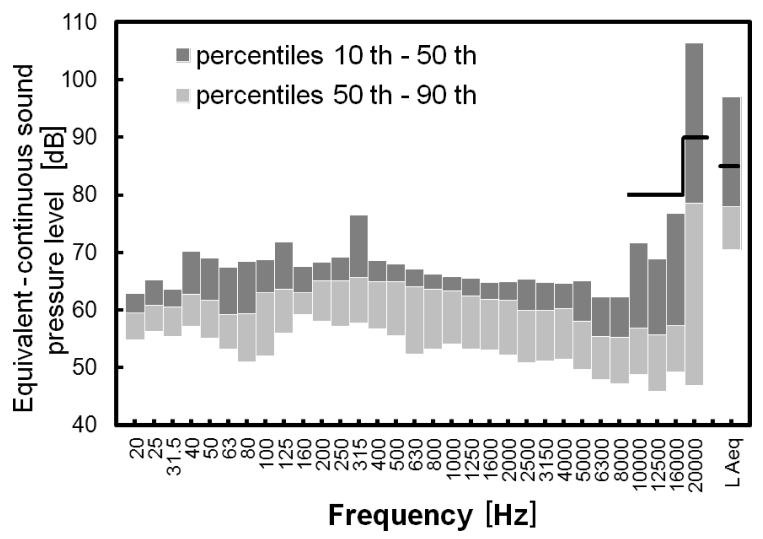

Fig. 2. Frequency spectrum of the audible noise at all examined work posts with low-frequency ultrasonic technological equipment. Bars show ranges between 10th percentiles and medians (marked in dark gray) or medians and 90th percentiles (marked in light gray) of the statistical distribution of sound pressure levels at $1 / 3$ octave frequency bands. Black lines present Polish maximum admissible intensity values (PMAI) for ultrasonic noise (in the frequency range of $10-20 \mathrm{kHz})$ and audible noise $\left(L_{\mathrm{EX}, 8 \mathrm{~h}}=85 \mathrm{~dB}\right)$.

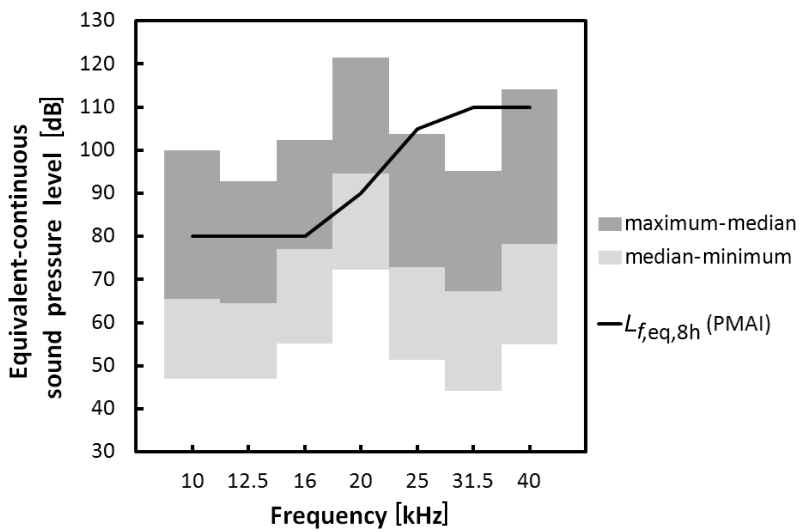

Fig. 3. Sound pressure level of the ultrasonic noise generated by the ultrasonic welding devices. Data concerns four factories where hearing tests and questionnaire surveys were performed. Bars show ranges between maximums and medians (marked in dark gray) or medians and minimums (marked in light gray) of the statistical distribution of sound pressure levels in the 1/3-octave frequency bands. Black line shows Polish maximum admissible intensity values of the equivalent-continuous sound pressure levels normalized to nominal 8-hour working day in $1 / 3$-octave frequency bands $\left(L_{f, \text { eq }, 8 \mathrm{~h}}(\mathrm{PMAI})\right)$. 
Table 2. The equivalent-continuous sound pressure levels (SPLs) normalized to nominal 8-hour working day and the maximum SPLs of ultrasonic noise generated by different low-frequencies ultrasonic technological equipment categorized into groups with respect to operating frequency. SPLs exceeding the Polish maximum admissible intensity values(PMAI) are marked in bold. Results concern all examined work posts.

\begin{tabular}{|c|c|c|c|c|c|c|c|}
\hline \multicolumn{8}{|c|}{$\begin{array}{l}\text { Median of the equivalent-continuous normalized to nominal 8-hour working day/maximum sound pressure levels } \\
\text { normalized to nominal 8-hour working day in 1/3-octave frequency bands, } L_{f, \text { eq }, 8 \mathrm{~h}} / L_{f, \max }[\mathrm{dB}]\end{array}$} \\
\hline 1/3-octave frequency bands, $f[\mathrm{kHz}]$ & 10 & 12.5 & 16 & 20 & 25 & 31.5 & 40 \\
\hline Ultrasonic cutters $/ 20 \mathrm{kHz}$ & $54.5 / 68.4$ & $55.6 / 68.7$ & $74.1 / 87.0$ & 93.2/106.4 & $75.5 / 89.0$ & $57.7 / 70.6$ & $70.9 / 84.7$ \\
\hline Other devices* $/ 25 \mathrm{kHz}$ & $60.7 / 83.5$ & $61.2 / 82.7$ & $60.8 / 89,5$ & $60.6 / 83.0$ & $62.5 / 84.1$ & $62.0 / 83.6$ & $61.1 / 82.0$ \\
\hline Other devices* $/ 31.5 \mathrm{kHz}$ & $68.5 / 79.2$ & $69.5 / 80.3$ & $70.8 / 80.6$ & $72.6 / 83.6$ & $74.0 / 87.9$ & $74.2 / 92.5$ & $71.3 / 82.7$ \\
\hline Washers $/ 20 \mathrm{kHz}$ & $53.6 / 61.0$ & $51.1 / 57.8$ & $69.9 / 76.4$ & $76.1 / 83.7$ & $55.0 / 61.6$ & $48.4 / 55.2$ & $53.5 / 58.1$ \\
\hline Washers $/ 31.5 \mathrm{kHz}$ & $55.4 / 67.4$ & $63.0 / 70.3$ & $70.4 / 83.3$ & $64.2 / 77.4$ & $68.4 / 78.8$ & $89.0 / 99.7$ & $72.8 / 87.4$ \\
\hline Washers $/ 40 \mathrm{kHz}$ & $49.3 / 63.8$ & $50.5 / 65.2$ & $57.8 / 72.1$ & $67.6 / 81.1$ & $56.1 / 70.3$ & $67.7 / 83.1$ & $86.2 / 101.6$ \\
\hline Welders**/20 kHz & $65.4 / 75.9$ & $64.5 / 74.9$ & $77.0 / 88.4$ & $94.6 / 106.6$ & $72.9 / 89.0$ & $67.3 / 84.0$ & $78.3 / 95.4$ \\
\hline Welders**/31.5 kHz & $65.2 / 71.0$ & $63.8 / 71.8$ & $66.0 / 80.6$ & $68.0 / 81.4$ & $77.9 / 93.3$ & $102.5 / 119.1$ & $99.9 / 116.0$ \\
\hline Welders ${ }^{* *} / 40 \mathrm{kHz}$ & $63.5 / 74.5$ & $63.2 / 73.1$ & $64.7 / 74.2$ & $78.7 / 87.4$ & $64.2 / 80.6$ & $79.9 / 97.4$ & $100.3 / 118.8$ \\
\hline Machines for textiles processing & $67.1 / 77.7$ & $74.7 / 82.9$ & $93.4 / 101.5$ & $110.5 / 120.5$ & $91.9 / 102.9$ & $78.7 / 88.5$ & $94.9 / 104.9$ \\
\hline Polish (PMAI) values; $L_{f, \text { eq }, 8 \mathrm{~h}} / L_{f, \max }$ & $80 / 100$ & $80 / 100$ & $80 / 100$ & $90 / 110$ & $105 / 125$ & $110 / 130$ & $110 / 130$ \\
\hline
\end{tabular}

* pest repellers, washers, ultrasonic cutters and scissors,

** welders and welding automats.

Table 3. Summary results of noise measurements at all examined work posts together with Polish maximum admissible intensity (PMAI) values for audible noise according to the Ordinance by the Minister of Labour and Social Policy (2014). ( $L_{C \text { peak }}, L_{A \text { max }}, L_{A \text { eq }}$ are $C$-weighted peak, $A$-weighted maximum and $A$-weighted equivalentcontinuous sound pressure levels, $L_{E X, 8 \mathrm{~h}}$ is noise exposure level normalized to a nominal 8-hour working day).

\begin{tabular}{|l|c|c|c|}
\hline Sound pressure level [dB] & $L_{C \text { peak }}$ & $L_{A \text { max }}$ & $L_{A \text { eq }}$ \\
\hline Minimum & 80.6 & 64.0 & 62.6 \\
\hline Median & 104.8 & 84.6 & 78.0 \\
\hline 90th Percentile & 112.0 & 101.5 & 96.1 \\
\hline Maximum & 117.9 & 107.3 & 104.0 \\
\hline PMAI values & 135.0 & 115.0 & $L_{\mathrm{EX}, 8 \mathrm{~h}}=85$ \\
\hline
\end{tabular}

Table 4. Noise exposure level normalized to a nominal 8 -hour working day averaged by the whole period of exposure to noise $\left(\left\langle L_{E X, 8 \mathrm{~h}}\right\rangle\right)$ at work posts occupied by workers who were exposed to ultrasonic and audible noise. Data concerns only study group.

\begin{tabular}{|l|c|}
\hline Sources of ultrasonic and audible noise & $\begin{array}{c}\left\langle L_{E X, 8 \mathrm{~h}}\right\rangle \\
{[\mathrm{dB}]}\end{array}$ \\
\hline Welding automats & 80.8 \\
\hline Welding automats and carving presses 1st & 80.7 \\
\hline Welding automats and carving presses 2nd & 81.1 \\
\hline Welders and carving presses & 80.1 \\
\hline Welders and welding automats & 80.4 \\
\hline $\begin{array}{l}\text { Welders, extruders and other devices gene- } \\
\text { rating audible noise }\end{array}$ & 80.8 \\
\hline Ultrasonic machines for textiles processing & 86.4 \\
\hline
\end{tabular}

\subsection{Hearing status}

The results of pure-tone audiometry and extendedhigh frequency audiometry (Figs. 4 and 5) of employees from the study group (exposed to ultrasonic and audible noise) were compared to the hearing thresholds of employees from the reference group (exposed to audible noise). Medians of hearing thresholds in the frequency range $0.5-6 \mathrm{kHz}$ were similar in both groups, but in the frequency range $8-14 \mathrm{kHz}$ medians of hearing thresholds were higher (worse) in the study group than in the reference group. The differences were statistically significant at 8 and $12.5 \mathrm{kHz}$ (Student $t$-test or U Mann-Whitney as necessary with the assumed significance level $p=0.05)$.

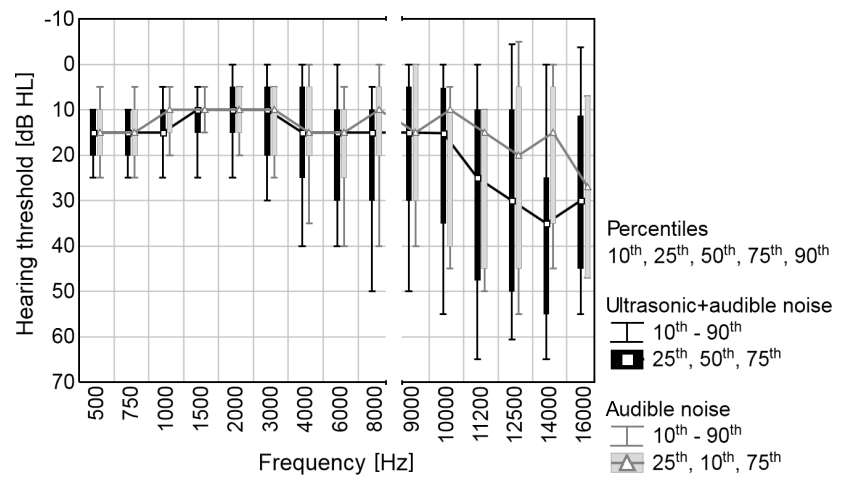

Fig. 4. Hearing thresholds in study group (exposed to ultrasonic and audible noise - marked in black) and reference group (exposed exclusively to audible noise - marked in gray). Percentiles of hearing threshold level distributions at different audiometric frequencies are marked with triangles or squares (50th), bars (25th and 75th) and whiskers (10th and 90th). 


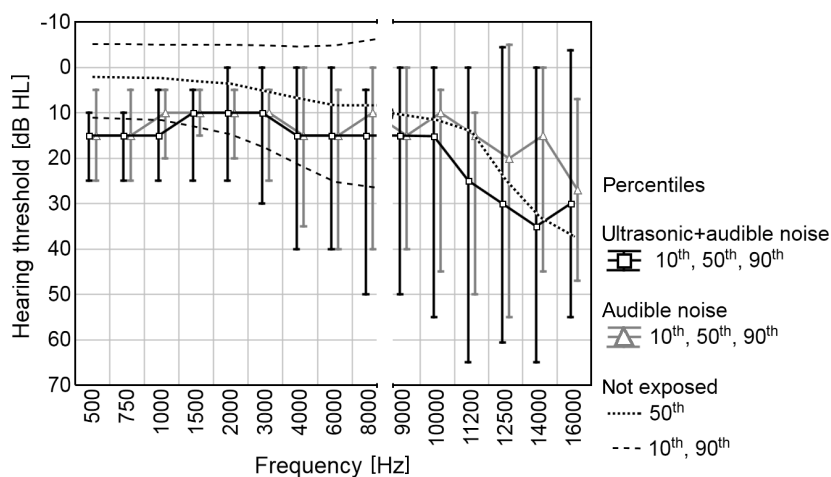

Fig. 5. Hearing threshold in study group (exposed to ultrasonic and audible noise - marked in black) and reference group (exposed exclusively to audible noise - marked in gray). Percentiles of hearing threshold distribution at different audiometric frequencies are marked with triangles or squares (50th) and whiskers (10th and 90th). Percentiles of statistical distribution of hearing thresholds in appropriate non-exposed to noise population, according to PN-EN ISO 7029:2004 and approximation according to JILEK et al. (2014) at frequencies above $8 \mathrm{kHz}$ where marked with dotted line for 50th percentile and with dashed lines for 10th and 90 th percentiles.

\section{Discussion}

Investigated low-frequency ultrasonic technological equipment was designed for various purposes, and therefore the ultrasonic noise generated by it had different sound pressure levels and different spectral composition. Work posts equipped with various types of ultrasonic welding devices were the most common and in these workplaces the ultrasonic noise levels were the highest.

In this study the hearing threshold levels in operators of welding devices were compared to both reference group exposed to audible noise (at similar $A$-weighted equivalent-continuous sound pressure level) and non-exposed populations according to PN-EN ISO 7029:2004 and (JILEK et al., 2014).

It should be noted that for selection of the reference group, the assessment of noise exposure of individual employees is important. When assessing the noise exposure level normalized to nominal 8-hour working day averaged over the whole period of employment, there is a problem connected with information on details of employment in conditions of exposure to noise in the course of earlier employment. Additionally, a lack of detailed information on the use of personal hearing protection devices may affect the outcome.

Workers involved in this study were exposed to audible noise at relatively low levels, i.e. at $\left\langle L_{\mathrm{EX}, 8 \mathrm{~h}}\right\rangle=$ $80.6 \mathrm{~dB}$ in case of group exposed to ultrasonic and audible noise, and $\left\langle L_{E X, 8 \mathrm{~h}}\right\rangle=81.8 \mathrm{~dB}$ in case of reference group (Table 1). Therefore, relative small permanent hearing threshold shifts were found up to $6 \mathrm{kHz}$ in both groups. Furthermore, in this frequency range hearing thresholds in both groups were similar (Fig. 4). At $8 \mathrm{kHz}$ hearing thresholds in the group exposed to audible noise were similar to those in the non-exposed population according to PN-EN ISO 7029:2004 (Fig. 5). Similar effect can be seen at $10-11.2 \mathrm{kHz}$. This may be related to the fact that at high frequencies, age-related adverse auditory effects predominate over those which were induced by audible noise (e.g. MACCA et al., 2015).

Hearing thresholds in the group exposed to ultrasonic and audible noise at higher frequencies were higher (statistically significant differences at 8 and $12.5 \mathrm{kHz}$ ) and there is a systematic increase in the threshold of hearing of people exposed to audible and ultrasonic noise which can be seen at high-frequencies above $8 \mathrm{kHz}$ (Fig. 4). Even at $9 \mathrm{kHz}$, the shape of distribution suggests that mean threshold level of this group is also higher.

Similar values of hearing thresholds at $16 \mathrm{kHz}$ in both groups are due to age. With age, the upper range of audible frequencies decreases and in people around the age of 40, it is about $15.5-16 \mathrm{kHz}$. LAWTON (2001) shows that only $10 \%$ of the 40 year old population can hear sounds at frequencies higher than $15 \mathrm{kHz}$.

The similarity of hearing threshold at $14 \mathrm{kHz}$ in group exposed to ultrasonic and audible noise and approximation by JILEK et al. (2014) may be associated with the selection of study group. This approximation was based on data from group comprising comparable numbers of women and men. The ratio of number of women to number of men was 1.2, while in our study group this ratio was equal to 2 . The approximation in the Fig. 5 does not depend on gender at extended high frequencies. JILEK et al. (2014) reported that many participants of their study had a significant $4 \mathrm{kHz}$ notch which shows that they had been exposed to noise. This, in turn, means that their study group was not selected from highly screened population.

Ahmed et al. (2001) and Somma et al. (2008) suggested that hearing at high frequency might be more sensitive to adverse noise-induced effects, particularly for younger groups. However, due to the given age and similar exposure to audible noise in both groups, and additional exposure to ultrasonic noise present only in one of them, it seems that additional exposure to ultrasonic noise is the reason for this difference. Similar results were obtained in previous studies. GRZESIK and Pluta $(1983,1986)$ observed additional hearing loss at range of 14 to $17 \mathrm{kHz}$ in workers exposed to ultrasonic noise in comparison to workers exposed to audible noise, which might have been caused by different frequency characteristic of noise. It seemed that the higher the hearing frequency, the higher the susceptibility to high-frequency noise.

The study presented by MACCA et al. (2015) showed statistically greater hearing deterioration at 
high frequencies (10 to $14 \mathrm{kHz}$ ) in group exposed to ultrasonic noise in comparison to group exposed to audible noise. This difference increases with age and period of work in exposure.

\section{Conclusions}

Hearing status of workers exposed to ultrasonic noise and audible noise is worse than hearing status of workers exposed exclusively to audible noise of similar $A$-weighted sound pressure levels.

Audiometric hearing thresholds in the frequency range $0.5-6 \mathrm{kHz}$ were similar in the study and reference groups, but in the frequency range of $8-12 \mathrm{kHz}$ were higher (worse) in the group of employees exposed to noise generated by the low-frequencies ultrasonic welding devices.

The preliminary analysis of the results of hearing research in both groups suggests that differences in hearing thresholds (at extended high frequencies) in the compared groups may result from differences in the spectral composition of the noise and support the need for further research.

\section{Acknowledgments}

This study was supported by the Ministry of Science and Higher Education of Poland (Grant IMP $17.2 / 2014-2015)$.

The control group was selected from data base collected during projects of the 6th European Framework Project "NoiseHear" (Contract MTKD - CT 2004 - 003137) and the European Social Found in Poland NFSR for years 2007-2013 (Project WND POKL.02.03.01 - $00-001 / 08$ ) and study supported by the Ministry of Science and Higher Education of Poland (Grant IMP 17.3/2014-2015).

\section{References}

1. Acton W.I., Hill C.R. (1977), Hazards of industrial ultrasound, Protection, 14, 19, 12-17.

2. Ahmed H.O., Dennis J.H., Badran O., Isamil M., Ballal S.G., Ashoor A., Jerwood D. (2001), High frequency $(10-18 \mathrm{kHz})$ hearing thresholds: reliability, and effects of age and occupational noise exposure, Occupational Medicine, 51, 4, 245-258.

3. Grzesik J., Pluta E. (1983), High-frequency hearing risk of operators of industrial ultrasonic devices, International Archives of Occupational and Environmental Health, 53, 77-88.

4. Grzesik J., Pluta E. (1986), Dynamics of high frequency hearing loss of operators of industrial ultrasonic devices, International Archives of Occupational and Environmental Health, 57, 137-142.
5. Jilek M., Suta D., Syka J. (2014), Reference hearing thresholds in an extended frequency range as a function of age, The Journal of the Acoustical Society of America, 136, 4, 1821-1830.

6. LaWton B.W. (2001), Damage to human hearing by airborne sound of very high frequency or ultrasonic frequency. Contract Research Report 343/2001, Health and Safety Executive, access 2016-03-10, http://www.hse.gov.uk/research/crr_pdf/2001/crr013 43.pdf.

7. Macca I., Scapellato M.L., Carrieri M., Maso S., Trevisan A., Bartolucci G.B. (2015), Highfrequency hearing thresholds: effects of age, occupational ultrasound and noise exposure, International Archives of Occupational and Environmental Health, 88, 197-211.

8. Minister of Labour and Social Policy (2014), The Regulation of 6 June 2014. On maximum permissible concentration and intensity of harmful factors in the work environment [in Polish: Rozporzadzenie Ministra Pracy i Polityki Spolecznej z dnia 6 czerwca 2014 r. w sprawie najwyższych dopuszczalnych stężen $i$ natężen czynników szkodliwych dla zdrowia w środowisku pracy], Journal of Law, item 817.

9. Pawlaczyk-Łuszczyńska M., Koton J., ŚliwińSka-Kowalska M., Augustyńska D., KameduŁA M. (2001a), Ultrasonic noise: documentation of maximum admissible values for occupational exposure [in Polish: Hałas ultradźwiękowy: dokumentacja proponowanych wartości dopuszczalnych poziomów narażenia zawodowego], Podstawy i Metody Oceny Środowiska Pracy, Warszawa CIOP, XVII, 28, 2, 5588.

10. Pawlaczyk-Łuszczyńska M., Koton J., AuguSTYŃSKA D. (2001b), Ultrasonic noise - measurement procedure [in Polish: Halas ultradźwiękowy - procedura pomiarowa], Podstawy i Metody Oceny Środowiska Pracy, Warszawa CIOP, XVII, 28, 2, 89-96.

11. PN-86/N-01321 (1986), Ultrasonic noise - Acceptable values of the sound pressure level at workstations and general requirements for measuring [in Polish: Hałas ultradźwiekowy. Dopuszczalne wartości poziomu ciśnienia akustycznego na stanowiskach pracy $i$ ogólne wymagania dotyczace wykonywania pomiarów], Polish Committee for Standardization Metrology and Quality, Warszawa.

12. PN-EN ISO 7029:2004 (2004), Acoustic - Statistical distribution of hearing thresholds as a function of age [in Polish: Akustyka - Statystyczny rozktad progów styszenia w funkcji wieku], Polish Committee for Standardization, Warszawa.

13. PN-EN ISO 9612 (2011). Acoustics - Determination of occupational noise exposure - Engineering method [in Polish: Akustyka - Wyznaczanie zawodowej ekspozycji na hatas - Metoda techniczna], Polish Committee for Standardization, Warszawa. 
14. PN-N-01307 (1994), Noise. Permissible values of noise in the workplace. Requirements for measurement [in Polish: Hatas - Dopuszczalne wartości parametrów hałasu w środowisku pracy - Wymagania dotyczace wykonywania pomiarów], Polish Committee for Standardization Metrology and Quality, Warszawa.

15. Minister of Labour and Social Policy (2014), The Regulation of 6 June 2014. On maximum permissible concentration and intensity of harmful factors in the work environment [in Polish: Rozporzadzenie Ministra Pracy i Polityki Spolecznej z dnia 6 czerwca 2014 r. w sprawie najwyższych dopuszczalnych stężeń $i$ natężen czynni- ków szkodliwych dla zdrowia w środowisku pracy], Journal of Law, item 817.

16. Smagowska B., Pawlaczyk-Łuszczyńska M. (2013), Effects of Ultrasonic Noise on the Human Body A Bibliographic Review, International Journal of Occupational Safety and Ergonomics (JOSE) 19, 2, 195202.

17. Somma G., Pietroiusti A., Magrini A., Coppetta L., Ancona C., Gardi S., Messina M., BergaMASCHI A. (2008), Extended high frequency audiometry and noise induced hearing loss in cement workers, American Journal of Industrial Medicine, 51, 452-462. 